\title{
PRODUCTIVE PERFORMANCE AND SEXUAL PUBERTY OF GROWING RAM LAMBS FED DIETS CONTAINING CONSERVED SUGAR BEET PULP \\ Youssef, Hafsa F. H. ${ }^{1}$; Y. H. Hafez ${ }^{1}$ and M. I. Bassiouni ${ }^{2}$ \\ ${ }^{1}$ Sheep and Goat Research Department, Animal Production Research Institute (APRI), Agricultural Research Center (ARC), Giza, Egypt. \\ ${ }^{2}$ Animal Production Department, Faculty of Agriculture, Kafr Elsheikh University.
}

\begin{abstract}
Twenty one growing crossbred ram lambs with average body weight of $19.67 \pm 0.42 \mathrm{~kg}$ and 4 months of age were divided into 3 similar groups (7 in each). All animals were fed diets consisted of $50 \%$ concentrate feed mixture (CFM) plus $50 \%$ berseem hay $(\mathrm{BH})$ in the $1^{\text {st }}$ group (control, G1) or plus $50 \%$ conserved mixture sugar beet pulp (SBP) $+\mathrm{BH}, 1: 1\}$ in the $2^{\text {nd }}$ group (G2) or plus $50 \%$ conserved mixture $(\mathrm{SBP}+\mathrm{BH}, 2: 1)$ in the $3^{\text {rd }}$ group (G3). Results showed that CP and CF contents decreased but NFE content increased in diets of G2 and G3 than in G1. Lambs in G2 showed the highest $(P<0.05)$ digestibility coefficients of all nutrients and TDN value, while, G1 showed the highest $(P<0.05) D C P$ value. Lambs in $G 3$ recorded the highest $(P<0.05)$ DM intake. The TDN intake was higher $(P<0.05)$ by $G 2$ and $G 3$ than $G 1$. Lambs in $G 1$ revealed the highest $(P<0.05) D C P$ intake. The highest $(P<0.05)$ ruminal $\mathrm{pH}$ value and $\mathrm{NH}_{3}-\mathrm{N}$ concentration was recorded in $\mathrm{G} 1$, while, $\mathrm{G} 2$ showed the highest $(P<0.05)$ ruminal TVFA's concentration. The highest $(P<0.05)$ concentrations of total protein, albumin and T4, was found in blood plasma of G2, while G1 had the highest concentrations of globulin, T3, urea-N, AST and ALT. Glucose concentration was nearly similar in all groups. Lambs in $G 2$ showed the heaviest $(P<0.05)$ weight, the highest $(P<0.05)$ total weight gain and average daily gain, followed by $G 3$, while $G 1$ had the lowest values $(P<0.05)$ Amount of $D M$ and $D C P / k g$ gain was higher $(P<0.05)$ for G1than $\mathrm{G} 2$ and $\mathrm{G} 3$. Amount of $\mathrm{TDN} / \mathrm{kg}$ gain was nearly similar in all groups. Economic feed efficiency was higher $(P<0.05)$ for $G 2$ and $G 3$ than $G 1$. Lambs in $G 2$ revealed the earliest $(P<0.05)$ age, the heaviest weight, the highest scrotal circumference and the highest testosterone concentration at age of puberty, followed by lambs in G3, while those in G1 had opposite trends. From these results it could be concluded that lambs fed diet containing conserved sugar beet pulp (50\% sugar beet pulp $+50 \%$ berseem hay) showed the best results concerning feed intake, digestibility, nutritive value, rumen fermentation activity, growth rate, feed conversion, economic efficiency and earliest age at puberty

Keywords: Ram lambs, conserved sugar beet pulp, digestion, gain, puberty.
\end{abstract}

\section{INTRODUCTION}

In Egypt, the total planted area of sugar beet was about 440 thousand feddans produced about 2.5 million tons fresh sugar beet pulp (Agricultural Economics, 2012). Sugar beet pulp is a byproduct of the sugar beet industry. After the sugar is extracted from the beet, the remaining fraction is mechanically pressed to around $24 \%$ dry matter. The pulp can be fed fresh or ensiled, allowing it to be accessible year round (Park et al., 2001). Sugar beet pulp could be used as a satisfactory source of energy in 
rations of lactating, growing and fattening ruminants (Haaksma, 1993; Mahmoud et al., 1998 and Mele et al., 1998).

Wet sugar beet pulp (WSBP) silages have a relatively high feedout value for livestock (Bell et al., 2001), which may be attributed to the highly digestible fiber fraction of WSBP (Tatlli et al., 2001). Introduction of 3\% sugar beet pulp to replace $50 \%$ of the common concentrate mixture is recommended in rations of growing sheep and could provide a safe source of carbohydrates with longer time of passage rate and consequently better utilization of dietary energy (El-Badawi and El-Kady, 2006).

In sugar beet pulp supplementation to forage feeding, as in the usual practice, the highly digestible fiber supplied by sugar beet pulp may have some effects on the degradation of forage fiber in the rumen. However, the feeding readily fermentable fiber and pectin in sugar beet pulp (Tanaka et al., 1993; Sadoya et al., 1995) might cause the change in rumen $\mathrm{pH}$, which then might influence the activity of rumen microbes involved in the fiber degradation of forages (Obara et al., 1991).

The objective of this study was to investigate the effect of feeding different proportions of sugar beet pulp and berseem hay in silages on nutrients digestibility, rumen activity, growth rate, economic efficiency and sexual behavior of growing lambs.

\section{MATERIALS AND METHODS}

The current study was conducted at Sakha Animal Production Research Station, Kafr El-Sheikh Province, belonged to Animal Production Research Institute, Agricultural Research Center in cooperation with Animal production Department, Faculty of Agriculture, Kafr El-Sheikh University.

Animals:

Total of twenty one growing crossbred ram lambs with average body weight of $19.67 \pm 0.42 \mathrm{~kg}$ and 4 months of age were divided according to body weight into 3 similar experimental groups (7 in each) fed three experimental diets. Animals were housed under a semi-roofed yard and kept under the same managerial conditions.

\section{Feeding system:}

Lambs in the $1^{\text {st }}$ group (G1) were fed a diet consisted of $50 \%$ concentrate feed mixture (CFM) and $50 \%$ berseem hay $(\mathrm{BH})$ and considered as a control group. Lambs in the $2^{\text {nd }}$ group (G2) were fed 50\% CFM plus 50\% of conserved mixture 1:1 of fresh sugar beet tops (SBP) and $\mathrm{BH}$. However, those in the $3^{\text {rd }}$ group (G3) were fed $50 \%$ CFM plus $50 \%$ of conserved mixture $2: 1$ of SBP and $\mathrm{BH}$, respectively.

All lambs were fed their allowances to cover the recommended requirements according to NRC (1985) for growing lambs and adjusted every two weeks according to body weight changes. The CFM was offered two times daily at 8 a.m. and 4 p.m., while roughages (BH or/and SBP) were offered once daily at 11 a.m. All lambs were kept under the routine veterinary supervision through the whole feeding period of 240 days. Lambs were allowed to drink water three times a day at 7 a.m., 1 p.m. and 7 p.m. 


\section{Ensiling process:}

Fresh sugar beet pulps were ensiled between feed toughs with added $50 \% \mathrm{BH}$ for $\mathrm{G} 2$ ) or $25 \% \mathrm{BH}$ for $\mathrm{G} 3$. About $30 \mathrm{~cm}$ layer of rice straw spread on the ground as bed to absorb seepage and to prevent contamination with earth. The silage materials were compressed by heavy drum filled with sand, then covered with plastic sheet, hard pressed with $30 \mathrm{~cm}$ of soil layer and ensiled for eight weeks.

\section{Experimental procedures:}

During the feeding period, body weight of lambs and feed intake were biweekly recorded individually for each experimental group. Lambs were weighed in the morning before drinking and feeding. Then, body gain, feed conversion and economic feed efficiency were calculated

Feed conversion was calculated as the amounts of DM, TDN and $\mathrm{DCP}(\mathrm{kg})$ required per $\mathrm{kg}$ live body weight gain. Economic efficiency expressed as the daily feed cost, price of daily weight gain, feed cost per $\mathrm{kg}$ gain and the ratio between price of daily weight gain and daily feed cost.

\section{Digestibility trials:}

Three digestibility trials were conducted simultaneously on 3 animals from each group after 4 months from the beginning of the experimental period to determine nutrients digestibility coefficients and nutritive values of the experimental diets using acid insoluble ash (AIA) as a natural marker according to Van Keulen and Young (1977). Faeces samples were taken from the rectum of each lamb twice daily at 12 hours interval during the collection period for 5 days. Representative samples of tested feedstuffs and faeces were taken at the beginning, middle and end of collection period to analyze according to AOAC (1990).

\section{Rumen liquor samples:}

During digestibility trials, rumen liquor samples were collected after 4 months from the beginning of the experiment from lambs at 3 hours after the morning feeding using a stomach tube and filtered through double layers of cheese cloth. Ruminal $\mathrm{pH}$ value was determined directly using Orian 680 digital $\mathrm{pH}$ meter, then samples were stored in dry clean glass bottles with added 2 drops of mercuric chloride and kept in deep freezer $\left(-20{ }^{\circ} \mathrm{C}\right)$ for chemical analyses. Concentration of total volatile fatty acids (VFA's) was determined in rumen liquor samples by the steam distillation method (Warner, 1964) using markham micro-distillation apparatus. The concentration of $\mathrm{NH}_{3}$ $\mathrm{N}$ was determined using saturated solution of magnesium oxide distillation according to AOAC (1990).

\section{Blood samples:}

Blood samples were withdraws from the jugular vein of three lambs in each group using sterile needle into clean dry heparinzed tubes and centrifuged at 4000 r.p.m. for 15 minutes to obtain plasma which was stoted at $-20{ }^{\circ} \mathrm{C}$ till analysis. In blood plasma, concentration of glucose, total proteins, albumin, urea-N, triiodothyronine (T3) and thyroxin (T4) as well as activity of asprtate (AST) and alanine (ALT) transaminases were determined calorimetrically using spectrophotometer and commercial diagnostic kits (Test-combination, Pasteur lap.). However, globuline concentration was determined by subtraction albumin fro total proteins concentration 


\section{Puberty detection:}

Ram lambs in all groups were subjected to observation to detect changes in sexual behavior, during the period from 3 months of age till the onset of puberty (first successful ejaculate with motile sperm). Five ewes were subjected to estrous synchronization by the hormonal treatment to ensure the availability of two ewes at least in oestrus at each time of libido test.

Age, weight, scrotal circumference and testosterone concentration were determined at different puberty stages, including $1^{\text {st }}$ mounting, mounting with erection ( $1^{\text {st }}$ penile protrusion) and puberty.

\section{Statistical analysis:}

Data were subjected to statistical analysis using general linear models (GLM) procedures adapted by SPSS for Windows (2008) with oneway ANOVA. Duncan test within program SPSS was done to determine the level of significance between the means (Duncan, 1955).

\section{RESULTS AND DISCUSSION}

\section{Chemical composition:}

Chemical composition of feedstuffs and the experimental diets is shown in Table (1). Fresh sugar beet pulp (SBP) had lower CP content and higher NFE content compared with berseem hay $(\mathrm{BH})$. So, CP content decreased but NFE content increased with increasing SBP and decreasing $\mathrm{BH}$ levels in the conserved mixture as presented in G2 and G3. The composition of experimental diets revealed that $\mathrm{CP}$ and $\mathrm{CF}$ contents decreased but NFE content increased in diets contained both conserved mixtures (G2 and G3) than that of control diet containing $\mathrm{BH}$ (G1).

The chemical composition of SBP is nearly similar to that obtained by Klebaniuk and Matras (1999).

\section{Digestibility coefficients and nutritive values:}

Digestibility coefficients and nutritive values of experimental diets are presented in Table (2). Lambs in $G 2$ showed significantly $(P<0.05)$ the highest digestibility coefficients of all nutrients, followed by lambs in G3 (for $\mathrm{DM}, \mathrm{OM}, \mathrm{CP}$ and EE) and in G1 (for CF and NFE). Meanwhile, G1 showed significantly $(P<0.05)$ the lowest digestibilities of DM, OM, CP and EE and G3 had the lowest digestibilities of CF and NFE.

Concerning the nutritive values of different experimental diets, dietary inclusion of both conserved mixtures significantly $(P<0.05)$ increased TDN in G2 and G3 as compared to BH (control, G1), but increasing SBP conserved mixture in diet of G3 showed significant reduction in TDN than in diet of G2. However, dietary inclusion of SBP conserved mixture significantly $(P<0.05)$ decreased DCP in $G 2$ and $G 3$, respectively as compared to $B H(G 1)$. These results confirmed with the higher NFE content of SBP and higher CP content of $\mathrm{BH}$ (Table 1). 
The obtained results agreed with those obtained by El-Badawi and El-Kady (2006) reported that dietary nutritive value expressed in terms of TDN was higher for the $50 \%$ SBP mixture than control.

Table (1): Chemical composition of feedstuffs and experimental diets.

\begin{tabular}{|l|c|c|c|c|c|c|c|c|}
\hline \multicolumn{1}{|c|}{ Item } & \multirow{2}{*}{ DM \% } & \multicolumn{7}{c|}{ Composition of DM (\%) } \\
\cline { 3 - 8 } & & OM & CP & CF & EE & NFE & Ash \\
\hline \multicolumn{7}{|c|}{ Feedstuffs: } \\
\hline CFM & 91.01 & 91.48 & 15.52 & 8.37 & 2.46 & 65.13 & 8.52 \\
\hline BH & 93.89 & 86.11 & 14.33 & 20.25 & 2.73 & 48.80 & 13.89 \\
\hline SBP & 25.08 & 94.08 & 7.87 & 18.34 & 2.11 & 65.76 & 5.92 \\
\hline $1^{1 \text { tt }}$ conversed mixture (G2) & 56.94 & 84.27 & 9.81 & 17.30 & 2.24 & 54.92 & 15.73 \\
\hline $2^{\text {nd }}$ conversed mixture (G3) & 41.28 & 85.21 & 7.94 & 16.79 & 1.97 & 58.51 & 14.79 \\
\hline \multicolumn{8}{|c|}{ Experimental diets: } \\
\hline G1 & 90.57 & 88.62 & 14.37 & 14.97 & 2.40 & 56.88 & 11.38 \\
\hline G2 & 73.53 & 88.15 & 12.60 & 12.59 & 2.22 & 60.74 & 11.85 \\
\hline G3 & 64.53 & 89.26 & 12.40 & 11.57 & 2.50 & 62.79 & 10.79 \\
\hline
\end{tabular}

Table (2): Digestibility coefficients (\%) and nutritive values (\%) of the experimental diets.

\begin{tabular}{|l|c|c|c|}
\hline \multicolumn{1}{|c|}{ Item } & G1 & G2 & G3 \\
\hline \multicolumn{4}{|c|}{ Digestibility coefficient (\%): } \\
\hline DM & $70.06 \pm 0.01^{\mathrm{c}}$ & $71.85 \pm 0.06^{\mathrm{a}}$ & $71.07 \pm 0.12^{\mathrm{b}}$ \\
\hline OM & $70.95 \pm 0.03^{\mathrm{c}}$ & $73.95 \pm 0.04^{\mathrm{a}}$ & $71.30 \pm 0.14^{\mathrm{b}}$ \\
\hline CP & $75.00 \pm 0.09^{\mathrm{c}}$ & $79.41 \pm 0.08^{\mathrm{a}}$ & $77.42 \pm 0.76^{\mathrm{b}}$ \\
\hline EE & $56.00 \pm 0.16^{\mathrm{c}}$ & $61.79 \pm 0.08^{\mathrm{a}}$ & $60.71 \pm 0.05^{\mathrm{b}}$ \\
\hline CF & $72.50 \pm 0.16^{\mathrm{b}}$ & $73.33 \pm 0.06^{\mathrm{a}}$ & $70.00 \pm 0.24^{\mathrm{c}}$ \\
\hline NFE & $73.79 \pm 0.10^{\mathrm{b}}$ & $74.87 \pm 0.52^{\mathrm{a}}$ & $72.24 \pm 0.03^{\mathrm{c}}$ \\
\hline \multicolumn{4}{|c|}{ Nutritive value (\%): } \\
\hline TDN & $65.06 \pm 0.004^{\mathrm{c}}$ & $67.25 \pm 0.010^{\mathrm{a}}$ & $65.85 \pm 0.008^{\mathrm{b}}$ \\
\hline DCP & $10.77 \pm 0.010^{\mathrm{a}}$ & $10.05 \pm 0.012^{\mathrm{b}}$ & $9.53 \pm 0.009^{\mathrm{c}}$ \\
\hline
\end{tabular}

a, b, c: Means in the same row with different superscripts are significantly different $(\mathbf{P}<0.05)$.

\section{Feed intake:}

Results in Table (3) showed that G3 recorded significantly $(P<0.05)$ the highest DM intake, followed by G2, while G1 had the lowest DM intake. The TDN intake by $G 2$ and $G 3$ was significantly higher $(P<0.05)$ than that of G1. However, G1 showed significantly $(P<0.05)$ the highest DCP intake, followed by G2, while G3 had the lowest DCP intake.

Table (3): Effect of dietary treatment on average daily feed intake by lambs.

\begin{tabular}{|l|c|c|c|}
\hline \multicolumn{1}{|c|}{ Item } & G1 & G2 & G3 \\
\hline Intake (g DM/d/h) & & 960 & 960 \\
\hline CFM & 960 & - & - \\
\hline BH & 991 & 1690 & - \\
\hline $1^{\text {st }}$ conversed mixture & - & - & 2425 \\
\hline $2^{\text {nd }}$ conversed mixture & - & 2650 & 3385 \\
\hline Total intake & 1951 & $1836 \pm 1.09^{\mathrm{b}}$ & $1876 \pm 2.12^{\mathrm{a}}$ \\
\hline Total DM intake & $1804 \pm 1.96^{\mathrm{c}}$ & $1235 \pm 1.45^{\mathrm{a}}$ & $1235 \pm 1.57^{\mathrm{a}}$ \\
\hline TDN & $1174 \pm 1.11^{\mathrm{b}}$ & $185 \pm 0.44^{\mathrm{b}}$ & $179 \pm 0.53^{\mathrm{c}}$ \\
\hline DCP & $194 \pm 0.34^{\mathrm{a}}$ & $\mathrm{m}$ & \\
\hline
\end{tabular}

$a, b, c:$ Means in the same row with different superscripts are significantly different $(P<0.05)$. 


\section{Rumen activity:}

Parameters of rumen activity in Table (4) showed that $\mathrm{G} 1$ revealed significantly $(P<0.05)$ the highest $\mathrm{pH}$ value followed by $\mathrm{G} 3$, while $\mathrm{G} 2$ had the lowest value. The $\mathrm{G} 1$ revealed significantly $(\mathrm{P}<0.05)$ the highest ruminal $\mathrm{NH}_{3}$ $\mathrm{N}$ concentration, followed by $\mathrm{G} 2$, while $\mathrm{G} 3$ had the lowest concentration. Moreover, G2 showed significantly $(P<0.05)$ the highest ruminal TVFA's concentration, followed by $\mathrm{G} 3$, while $\mathrm{G} 1$ had the lowest concentration.

These results agreed with those obtained by Rouzbehan et al. (1996), who reported that ruminal ammonia concentration reduced and TVFA's concentration increased during feeding sheep diets supplemented with SBP. Also, Salman et al. (2008) found that ruminal TVFA's concentration was significantly higher for goats fed SBP rations than the control group.

Table (4): Effect of dietary treatment on rumen activity of lambs.

\begin{tabular}{|l|c|c|c|}
\hline \multicolumn{1}{|c|}{ Item } & G1 & G2 & G3 \\
\hline $\mathrm{pH}$ value & $5.81 \pm 0.01^{\mathrm{a}}$ & $5.28 \pm 0.02^{\mathrm{c}}$ & $5.61 \pm 0.01^{\mathrm{b}}$ \\
\hline $\mathrm{NH}_{3}-\mathrm{N}(\mathrm{mg} / 100 \mathrm{ml})$ & $24.38 \pm 0.01^{\mathrm{a}}$ & $23.96 \pm 0.01^{\mathrm{b}}$ & $23.46 \pm 0.01^{\mathrm{c}}$ \\
\hline TVFA's $(\mathrm{mq} / 100 \mathrm{ml})$ & $16.46 \pm 0.04^{\mathrm{C}}$ & $18.82 \pm 0.02^{\mathrm{a}}$ & $17.70 \pm 0.01^{\mathrm{b}}$ \\
\hline
\end{tabular}

a, b, c: Means in the same row with different superscripts are significantly different $(P<0.05)$.

\section{Blood parameters:}

Blood plasma parameters in Table (5) revealed significant $(P<0.05)$ effect of dietary treatment on concentrations of total proteins (TP), albumin (AL), globulin (GL), urea-N, T3 and T4 as well as activity of AST and ALT. Concentration of TP, AL and T4 was significantly $(P<0.05)$ the highest in blood plasma of lambs in G2.

Table (5): Effect of dietary treatment on blood parameters of lambs.

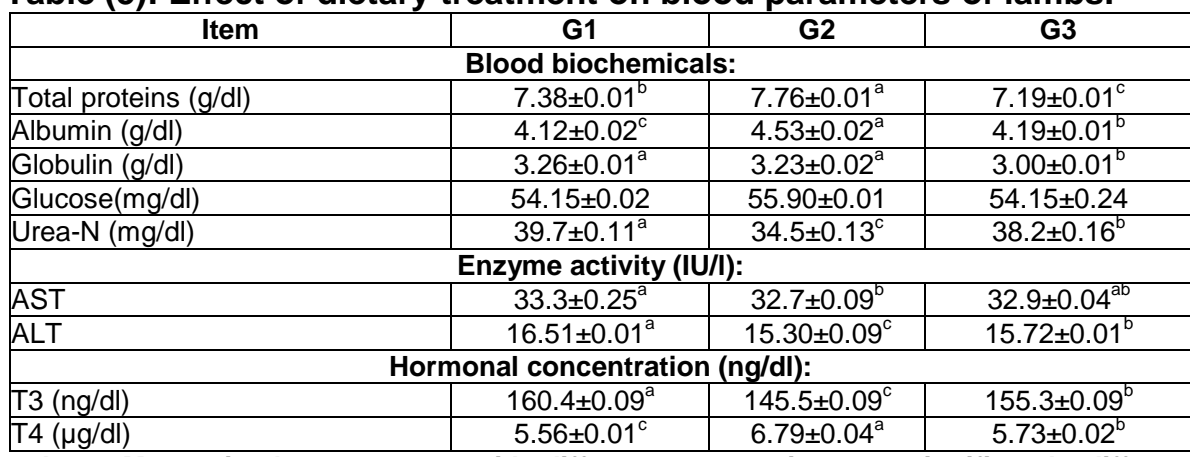

a, b, c: Means in the same row with different superscripts are significantly different $(P<0.05)$.

Concentration of GL, T3 and urea-N as well as activity of AST and ALT was significantly $(P<0.05)$ the highest in blood plasma of lambs in $G 1$. However, glucose concentration was nearly similar for the different groups.

In accordance with the obtained results, Enaeme et al. (1990) observed no typical pattern in plasma concentration of glucose, while plasma urea concentration increased with feeding growing fattening bulls on SBP 
diet. Also, Belibasakis et al. (1996) reported that feeding dairy cows on SBP increased concentration of TP, AL and urea.

Growth performance:

Growth performance parameters of lambs fed experimental diets are presented in Table (6). Lambs in G2 showed significantly $(P<0.05)$ the heaviest final body weight and the highest total weight gain and average daily gain, followed by those in G3, while the control lambs (G1) had the lowest values. Results indicated that average daily gain of lambs in G2 and G3 increased by 10.05 and $4.76 \%$ than that of $\mathrm{G} 1$, respectively. These results confirmed with higher TDN value (Table 2) and TVFA's concentration (Table 4) for G2. In agreement with the present results, Ali et al. (2000) found the addition of SBP to sheep rations caused an increase in body weight gain. Also, El-Badawi and El-Kady (2006) found that inclusion of SBP at $50 \%$ of the common CFM increased average daily gain of lambs.

Feed conversion expressed as the amounts of DM, TDN and DCP per $\mathrm{kg}$ gain presented in Table (6) showed that the amount of $\mathrm{DM} / \mathrm{kg}$ gain was significantly $(P<0.05)$ higher for $\mathrm{G} 1$ and $\mathrm{G} 3$ than that of $\mathrm{G} 2$.

The amount of $D C P / \mathrm{kg}$ gain was significantly $(P<0.05)$ higher in $\mathrm{G} 1$ than in G2 and G3. However, the amount of TDN/kg gain was nearly similar for all groups.

Table (6): Effect of dietary treatment on growth performance of lambs.

\begin{tabular}{|c|c|c|c|}
\hline Item & G1 & G2 & G3 \\
\hline \multicolumn{4}{|c|}{ Growth parameters: } \\
\hline Initial body weight (kg) & $19.86 \pm 0.55$ & $19.57 \pm 0.57$ & $19.57 \pm 0.48$ \\
\hline Final body weight(kg) & $46.86 \pm 1.08^{b}$ & $49.29 \pm 0.57^{\mathrm{a}}$ & $47.86 \pm 0.67^{\mathrm{ab}}$ \\
\hline Total weight gain $(\mathrm{kg})$ & $27.00 \pm 0.72^{b}$ & $29.71 \pm 0.18^{a}$ & $28.29 \pm 0.29^{\mathrm{ab}}$ \\
\hline Average daily gain (g/day) & $112.50 \pm 3.02^{b}$ & $123.81 \pm 0.77^{a}$ & $117.86 \pm 1.19^{\mathrm{ab}}$ \\
\hline \multicolumn{4}{|c|}{ Feed conversion: } \\
\hline Kg DM/kg gain & $16.10 \pm 0.43^{\mathrm{a}}$ & $14.83 \pm 0.09^{b}$ & $15.93 \pm 0.15^{\mathrm{a}}$ \\
\hline $\mathrm{Kg}$ TDN/kg gain & $10.48 \pm 0.28$ & $9.97 \pm 0.06$ & $10.48 \pm 0.10$ \\
\hline $\mathrm{Kg} \mathrm{DCP} / \mathrm{kg}$ gain & $1.73 \pm 0.05^{\mathrm{a}}$ & $1.49 \pm 0.01^{b}$ & $1.51 \pm 0.02^{b}$ \\
\hline \multicolumn{4}{|c|}{ Economic evaluation: } \\
\hline Daily feed cost (LE) & $2.79 \pm 0.07$ & $2.79 \pm 0.06$ & $2.73 \pm 0.09$ \\
\hline Price of daily gain (L.E.) & $3.15 \pm 0.10^{b}$ & $3.47 \pm 0.14^{\mathrm{a}}$ & $3.30 \pm 0.12^{\mathrm{ab}}$ \\
\hline Economic efficiency \% & $112.9 \pm 0.25^{b}$ & $124.4 \pm 0.29^{a}$ & $120.9 \pm 0.23^{a}$ \\
\hline
\end{tabular}

a, b, c: Means in the same row with different superscripts are significantly different $(P<0.05)$.

Price of CFM, BH and SBP was 2020, 858 and 150 L.E./ton. Price of kg gain was 28 L.E.

These results agreed with those obtained by El-Badawi and El-Kady (2006), who found that feed conversion in terms of $\mathrm{kg}$ DM or TDN per $\mathrm{kg}$ gain was significantly $(P<0.05)$ better for growing sheep fed $50 \%$ SBP. Data of economic efficiency (Table 6) revealed that in spite of the lower price of SBP than $\mathrm{BH}$, average daily feed cost was nearly similar for all groups due to increasing the roughage intake with increasing the proportion of SBP. Lambs in $G 2$ showed significantly $(P<0.05)$ the highest price of daily gain followed by those in G3, while those in G1 had the lowest value. Therefore, economic feed efficiency was significantly $(P<0.05)$ higher for $G 2$ and $G 3$ compared to G1 (control). 
These results agreed with those obtained by Ali et al. (2000) who found the addition of sugar beet pulp to sheep rations decreased the feed cost for producing one $\mathrm{kg}$ of live body weight gain.

Sexual puberty of ram lambs:

According to sexual puberty stages, lambs in G2 showed significantly $(\mathrm{P}<0.05)$ the shortest ages and the heaviest weights at $1^{\text {st }}$ stage $\left(1^{\text {st }}\right.$ mounting), $2^{\text {nd }}$ stage (mounting and $1^{\text {st }}$ erection) and $3^{\text {rd }}$ stage (mounting, erection and $1^{\text {st }}$ ejaculation), indicating earliest age at puberty, followed by lambs in G3, while the control lambs showed the latest ages and the lightest weights at puberty (Table 7 ).

It is of interest to note that the earliest ages of lambs in G2 at different puberty stages was associated with the highest scrotal circumference and testosterone concentration, followed by lambs in G3, while those in G1 showed the lowest values (Table 7).

Table (7): Sexual behavior of ram lambs fed experimental diets.

\begin{tabular}{|c|c|c|c|}
\hline Item & G1 & G2 & G3 \\
\hline \multicolumn{4}{|c|}{$1^{\text {st }}$ mounting: } \\
\hline Age (day) & $208.86 \pm 0.67^{\mathrm{a}}$ & $195.00 \pm 0.31^{\mathrm{c}}$ & $200.00 \pm 0.44^{b}$ \\
\hline Body weight (kg) & $28.20 \pm 0.09^{C}$ & $30.20 \pm 0.05^{\mathrm{a}}$ & $28.90 \pm 0.10^{b}$ \\
\hline Scrotal circumference $(\mathrm{cm})$ & $23.51 \pm 0.10^{b}$ & $24.73 \pm 0.02^{\mathrm{a}}$ & $24.07 \pm 0.85^{\mathrm{ab}}$ \\
\hline Testosterone $(\mathrm{ng} / \mathrm{ml})$ & $3.70 \pm 0.05^{\mathrm{b}}$ & $4.40 \pm 0.05^{\mathrm{a}}$ & $4.30 \pm 0.07^{\mathrm{a}}$ \\
\hline \multicolumn{4}{|c|}{$1^{\text {st }}$ mounting with erection: } \\
\hline Age(day) & $227.00 \pm 0.49^{a}$ & $224.14 \pm 0.91^{b}$ & $225.00 \pm 0.62^{\mathrm{ab}}$ \\
\hline Body weight(kg) & $32.40 \pm 0.18^{b}$ & $32.80 \pm 0.03^{\mathrm{a}}$ & $32.50 \pm 0.03^{\mathrm{ab}}$ \\
\hline Scrotal circumference $(\mathrm{cm})$ & $26.13 \pm 0.08^{b}$ & $26.96 \pm 0.04 a$ & $26.86 \pm 0.02^{a}$ \\
\hline Testosterone (ng/ml) & $3.40 \pm 0.05^{\mathrm{b}}$ & $3.61 \pm 0.04 a$ & $3.50 \pm 0.03^{\mathrm{ab}}$ \\
\hline \multicolumn{4}{|c|}{$1^{\text {st }}$ ejaculation (puberty): } \\
\hline Age (day) & $247 \pm 0.79^{a}$ & $240 \pm 1.09^{b}$ & $245 \pm 0.49^{\mathrm{a}}$ \\
\hline Body weight(kg) & $34.7 \pm 0.05^{c}$ & $35.7 \pm 0.08^{\mathrm{a}}$ & $35.4 \pm 0.09^{b}$ \\
\hline Scrotal circumference $(\mathrm{cm})$ & $28.68 \pm 0.04^{b}$ & $28.99 \pm 0.02^{a}$ & $28.93 \pm 0.05^{\mathrm{a}}$ \\
\hline Testosterone $(\mathrm{ng} / \mathrm{ml})$ & $1.10 \pm 0.01^{\mathrm{c}}$ & $1.31 \pm 0.01^{\mathrm{a}}$ & $1.19 \pm 0.01^{\mathrm{b}}$ \\
\hline
\end{tabular}

$a, b, c:$ Means in the same row with different superscripts are significantly different $(P<0.05)$.

It is worth noting, that younger age of lambs in G2 at the $1^{\text {st }}$ and $3^{\text {rd }}$ stage of puberty was associated with the highest ADG of ram lambs in G2. The increase in feed intake was associated with increase in testicular weight (Cupps, 1993).

In this respect, Walkden-Brown et al. (1994) suggested that testicular mass appears to be primarily dependent on changes in voluntary feed intake and growth of goats. Also, Perez-Clarig et al. (1998) concluded that improved nutrition accelerated the testicular growth and a transit increase occurred pulstile secretion of LH. Moreover, Miller et al. (1998) suggested that when nutritional status of male sheep was improved, insulin, amino acids and possibly glucose interacted to modulate $\mathrm{GnRH}$ secretion.

In accordance with the present results, Kumi-Diaka et al. (1985) found that at 6.4 months of age, scrotal circumference was $18.5 \mathrm{~cm}$ in intensively managed ram lambs. In the extensively managed animals, scrotal circumference decreased downward $15.2 \mathrm{~cm}$ at 7.8 months of age. Age of puberty of ram lambs under sub-tropical conditions was earlier (6.4 months) 
and scrotal circumference was wider $(18.5 \mathrm{~cm})$ in intensively managed animals as compared to extensively managed animals (age at puberty and scrotal circumference were 7.8 months and $15.2 \mathrm{~cm}$, respectively.

In Corriedule ram lambs, Castrillejo et al. (1995) found that onset of puberty attained earlier at 180-216 days of age with nearly similar scrotal circumference $(23 \mathrm{~cm})$ to that obtained in the present study. The present trend of increase in scrotal circumference at all stages of puberty was similar to that obtained by Ali and El-Saidy (2003) and El-Saidy et al. (2004), who found that at first ejaculation (puberty) ram lambs fed $50 \%$ dry sugar beet tops (DSBT) showed significantly wider scrotal circumference than that of ram lambs fed $\mathrm{BH}$ or $100 \%$ DSBT.

The present values of testosterone concentration in blood plasma of all groups at puberty are within the ranges reported by Schanbacher and Crouse (1980) in Suffolk ram lambs (0.8 and $3.4 \mathrm{ng} / \mathrm{ml})$, but it was higher than values reported by El-Shamaa (2002) in Romanov crossbred ram lambs $(1.45-2.70 \mathrm{ng} / \mathrm{ml})$ and by El-Badawy (2003) in Finnish crossbred ram lambs $(2.06-2.54 \mathrm{ng} / \mathrm{ml}$. These differences may be attributed to wide variation in sheep breed, environmental conductions and feeding level.

From these results it could be concluded that lambs fed diet containing conserved sugar beet pulp mixture (50\% sugar beet pulp $+50 \%$ berseem hay) showed the best results concerning feed intake, digestibility, rumen fermentation activity, growth rate, feed conversion, economic efficiency and earliest age at puberty.

\section{REFERENCES}

Agricultural Economics (2012). Central Administration, Agricultural Economics. Winter Crops. Economic Affairs Sector, Ministry of Agric., Egypt.

Ali, M.F.; M.K. Mohsen; M.I. Bassiouni and M.M. Khalafalla (2000). The influence of using dried sugar beet pulp on sheep performance. J. Agric. Res. Tanta Univ., 26(2): 132-144.

Ali, M.F. and B.E. El-Saidy (2003). The effect of feeding dried sugar beet tops on the productive and reproductive performance of ram lambs. J. Agric. Sci. Mansoura Univ., 28(8): 5969-5983.

AOAC (1990). Official Methods of Analysis. Vol. I (15 ${ }^{\text {th }}$ Ed.). Association of Official Analytical Chemists, Arlington, VA.

Belibasakis, N.G.; E. Progia and A. Papaioannou (1996). Effects of dried molassed sugar beet pulp on milk production, milk composition and blood components of dairy cows. Zivocisna Vyroba, 41(10): 451-454.

Bell, J.F.; D.J. Roberts and K.A. Leach (2001). The effect of feeding forage maize ensiled with sugar beet pulp to dairy cows. Proc. of the Brit. Soc. of Anim. Sci., p. 148-159.

Castrillejo, A.; A. Morana; A. Bielli; T. Gasted; J.R. Molina; M. Forsberg and $\mathrm{H}$. Martines (1995). Onset of spermatogenesis in Corriedale ram lambs under extensive rearing condition in Uruguay. Brit. Vet., 145(3): 276-288. 
Cupps, P.T. (1993). Reproduction in Domestic Animals. $4^{\text {th }}$ Edition, California, Academic Press, Inc.

Duncan, D.B. (1955). Multiple Range and Multiple F-Tests. Biometric, 11: 142.

El-Badawy, A.M.M. (2003). Nutritional and physiological studies in ruminants. M. Sc. Thesis, Fac. of Agric. Mansoura Univ.

El-Badawi, A.Y. and R.I. El-Kady (2006). Effect of partial replacement of concentrates with sugar beet pulp on performance, carcass characteristics and energy utilization of growing sheep. International Journal of Agriculture and Biology, 8(3): 344-348.

El-Saidy, B.E. (2004). Seasonal variations in the reproductive performance of crossbred Finnish rams (Finnish x Rahmani) in Egypt. Alex. J. Agric. Res. 49(1): 11-24.

El-Shamaa, I.S. (2002). Onset of puberty, semen production and blood constituents in crossbred male lambs as affected by dietary yeast culture addition. J. Agric. Sci. Mansoura Univ., 27(7): 4589-4598.

Enaeme, C. Van; L. Lstasse; A. Gabriel; A. Clinquart; G. Maghuim and J.M. Bienfait (1990). Effects of dietary carbohydrate composition on rumen fermentation, plasma hormones and metabolites in growing-fattening bulls. Anim. Prod., 50(3): 409-416.

Haaksma, J. (1993). Sugar beet pulp in diets for dairy cows. Mededeling Institute Voor Rationele Suiker Producktite, 27-46 PP.

Kumi-Diaka, T.K.; V.O. Djang-Fordjiour and D. Ogwu (1985). Effect of different husbandry systems on the reproductive development of postweaning ram lambs under tropical conditions. Theriogenology, Vol. 23:583-591.

Klebaniuk, R. and J. Matras (1999). Structure of production quality of silages in the farms of Zamosc district, specializing in rearing of dairy cattle. Annales Universitatis, Mariae Curie Sklodowska Secto-EE-Zootechnia, 17: 383-388.

Mahmoud, S.A.; G. El-Santiel and M.F. Ali (1998). Dried sugar beet pulp as a grain replacement in sheep rations. J. Agric. Res. Tanta Univ., 24(2): 118-126.

Miller D.W.; D. Blache and G.B. Martin (1998). The role of intracerebral insulin in the effect of nutrition on gonadotrophin secretion in mature male sheep. Journal of Endocrinology, 147(2): 321-329.

Mele, M.; J. Puhan and A. Pen (1998). Evaluation of bovine fed supplemented with preserved by-products of sugar beet processing. Zbornik predavanj posvetovanja of prehranidomacih ziali zadravceviergavcevi dnevi Radenci, 26 in 27 Oktober, 224-229 (Abst.).

NRC (1985). National Research Council. Nutrient Requirements of Sheep $6^{\text {th }}$ Rev. Ed. National Academy of Science, Washington, D.C. USA.

Obara, Y.; D.W. Dellow and J.V. Nolan (1991). The influence of energy-rich supplements on nitrogen kinetics in ruminants. In "Physiological Aspects of Digestion and Metabolism in Ruminants". Academic Press, Inc. San Diego. Pp. 515-539. 
Park, J.; I.G. Rush; B. Weichenthal and T. Milton (2001). The effect of feeding pressed sugar beet pulp in beef cattle feedlot finishing diets. Nebraska Beef Cattle Reports. http://digitalcommons.unl.edu/animalscinbcr/312.

Perez-Clarig, R.; J. Bermudez; H. Anderssen and J. Burguena (1998). Influence of nutrition on testicular growth in Corriedale rams during spring. Reprod. Nutr. Dev., 38(5): 529-538

Rouzbehan, Y.; H. Galbraith; J.H. Topps and J. Rooke (1996). The response of sheep to big bale silage ensiled with or supplemented separately with molassed sugar beet feed. Anim. Feed Sci. and Tech., 59(4): 279284.

Sadoya, H.; T. Sato; K. Tanaka and M. Okamoto (1995). Feeding values of beet pulp compared with corn, grass hay and alfalfa hay cube. Anim. Sci. Technol., 66: 540-547.

Salman, F.M.; R.I. El-Kadi; H. Abdel-Rahman; S.M. Ahmed; M.I. Mohamed and M.M. Shoukry (2008). Biologically treated sugar beet pulp as a supplement in goat rations. International Journal of Agriculture and Biology, 10(4): 412-416.

Schanbacher, B.D. and J.D. Crouse (1980). Growth and performance of growing Finishing lamb exposed to long or short photo periods. J. Anim. Sci., 51: 943.

SPSS (2008). Statistical Package for the Social Sciences, Release: 16, SPSS Inc, Chicago, USA.

Tanaka, K.; T. Aritsuka; H. Sadoya; T. Sato and M. Okamoto (1993). Settling volume, water holding capacity and fermentation characteristics of dried beet pulp and extracted carbohydrates in an artificial rumen. Anim. Sci. Technol., 64: 1201-1207.

Tatlli, P.; I.H. Cerci and F. Gurdogan (2001). The determination of ensiled qualities of com, alfalfa, and sugar beet pulp and the effects on food intake and nutrient digestibility when fed to lambs in different forms. Turk. J. Vet. Anim. Sci., 25: 403-407.

Van Keulen, J.V. and B.A. Young (1977). Evaluation of acid insoluble ash as a natural marker in ruminant digestibility studies. J. Anim. Sci., 44: 282-287.

Walkden-Brown S.W.; B.J. Restall; B.W. Norton; R.J. Scaramuzzi and G.B. Martin (1994). Effect of nutrition on seasonal patterns of LH, FSH and testosterone concentration, testicular mass, sebaceous gland volume and odour in Australian Cashmere goats. Journal of Reproduction and Fertility, 102: 351-360.

Warner, A.C.I. (1964). Production of volatile fatty acids in the rumen. Methods of Measurements. Nut. Abst. Rev. 34: 339. 


\section{Youssef, Hafsa F. H. et al.}

الأداء الإتتاجى والبلوغ الجنسى للحملان النامية المغذاة على علائق محتوية على النقى تفل بنجر السكر المحفوظ

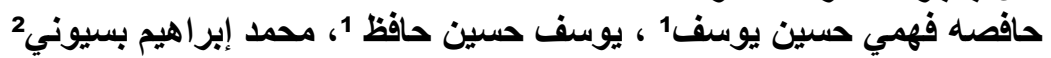

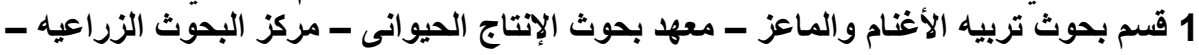
الجيزه- مصر. فئ. 2 قسم الإنتاج الحيواني - كلية الزراعه - جامعة كفر الثيخ.

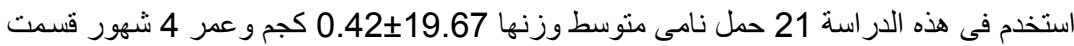

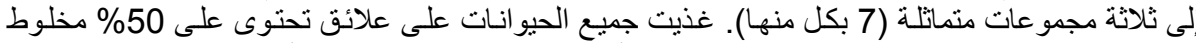

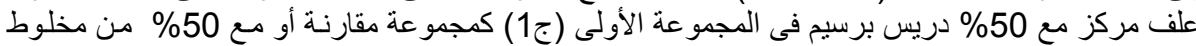

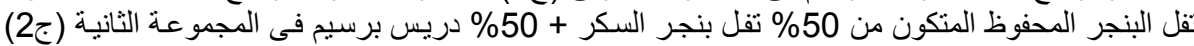
أو مع 50\% المخلوط الثاني الذي تكون من 75\% ب تفل بنجر السكر + 25\% دريس برسيم فى المجموعة

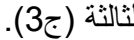

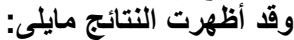
1- ارتفاع محتوى البروتين و الألياف وانخفاض محتوى المستخلص الخالى من الأزوت في العنى العلائق المحتويـة

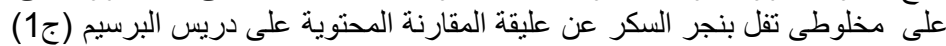

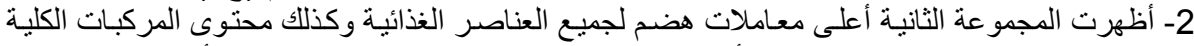

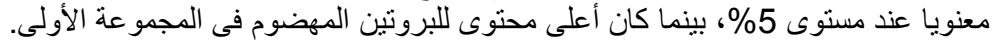

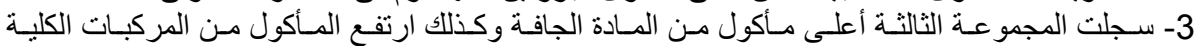

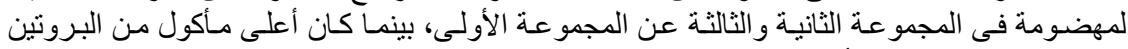

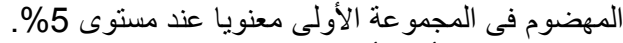

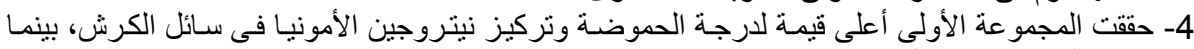

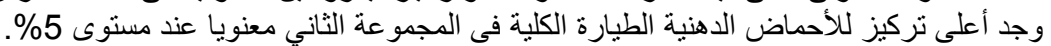

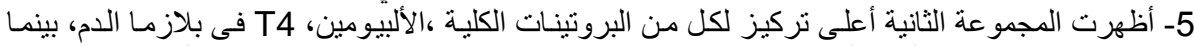

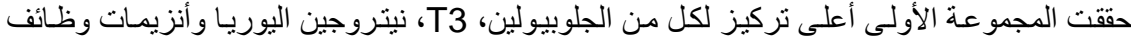

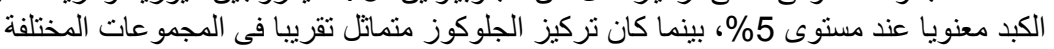

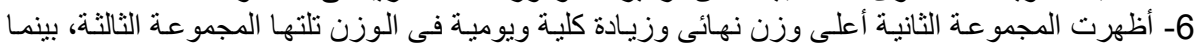

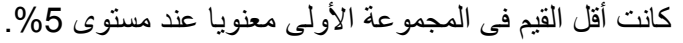

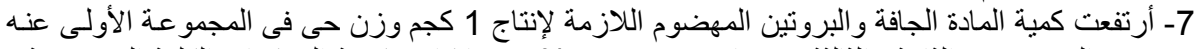

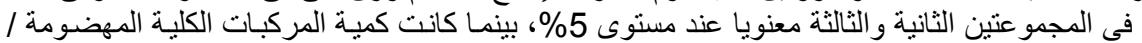

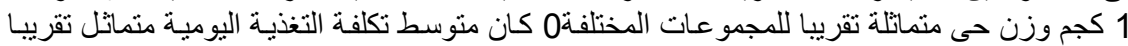
في المجمو عات المختلفة

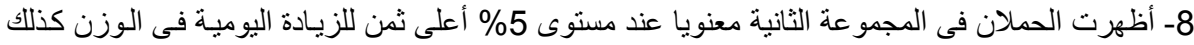

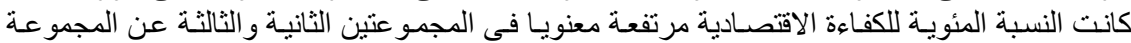

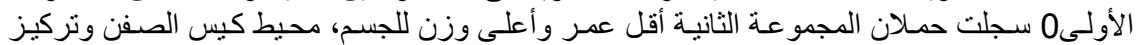

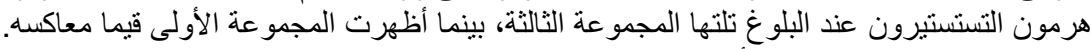

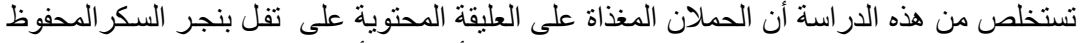

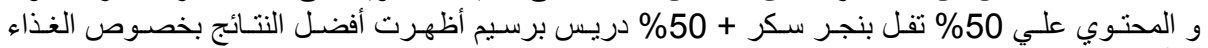

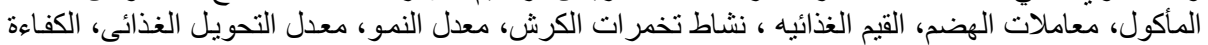
الاقتصادية و البلوغ الجنسى.

كلية الزراعة - جامعة المنصورة مركز البحوث الزراعية
قام بتحكيم البحث

أ.د / عبد الخالق السيد عبد الخالق أ.د / محمود محمد بندارى الدي 